\title{
ANTECEDENTS OF COOPERATION OF PUBLIC HIGHER EDUCATION INSTITUTIONS WITH EXTERNAL ENTITIES. LITERATURE APPROACH
}

\author{
Aleksandra Pisarska*, Jarosław Karpacz**
}

\begin{abstract}
Background. This study is a part of a debate with reference to selected public sector organisations, such as public higher education institutions. Its aim is to identify the antecedences of cooperation of public higher education institutions with external entities. The given issue is important since the task of public higher education institutions, and their subsystem of interorganisational relations in particular, is to create favourable conditions for their proper adjustment to the environment, with a guarantee of their effectiveness at the same time.
\end{abstract}

Research aims. The aim of this study is to identify the antecedence of building relations between public higher education institutions and external partners, as well as the areas in which those relations are used by cooperating entities in order to achieve their goals. The structure of this study has been conformed with this aim. The first part of the study presents the characteristics of relations between the public sector organisations and external entities. In the second part there is focus on identifying the essence of functioning of public higher education institutions and the specific character of their relations with external stakeholders. The third part, on the basis of the results of literature analysis, indicates the antecedences of cooperation of public higher education institutions with external entities.

Methodology. The content of this article is the result of a conducted study of literature in the scope of public management, interorganisational relations and the functioning of public higher education institutions. The study has been executed in compliance with - proper for this research method - a specific methodological rigour: starting from defining the aim of a research task, through selecting publications, analysing contents and elaborating the results.

Key findings. Public higher education institutions, by creating relations with external organisations, aim at an effective realisation of tasks imposed on them by the Act on Higher Education. It is especially expected that the above-mentioned relations will contribute to increasing the economic and social effectiveness of

* The Jan Kochanowski University in Kielce. E-mail: a.pisarska@ujk.edu.pl

** The Jan Kochanowski University in Kielce. E-mail: j.karpacz@ujk.edu.pl 
higher education institutions. However, it is mostly expected that higher education institutions, by taking advantage of relations with other organisations, will contribute to the development of knowledge. In the light of the obtained research results, identifying the types of relations between public higher education institutions and particular external entities, and simultaneously determining the level of dependence of their actions on their partners' undertakings, seems to be intriguing.

Keywords: public higher education institutions, interorganisational relations, cooperation.

\section{INTRODUCTION}

The emerging landscape of the public sector organisations, which is more and more frequently leaning towards providing public services within relations with other autonomous commercial, quasi-commercial, and voluntary organisations, is one of the symptoms of the social, political, and economic changes which have been taking place for the past two decades in Poland and in the rest of the world. The role of public authorities is also undergoing a shift (which is worth to be emphasised) from the previous position of a public services provider to the position of a manager of those services.

Hence, present public organisations undertake actions in the public interest and they realise their aims mainly via building cooperation relations with other entities (Kożuch, 2011, p. 14), which in fact makes them dependent on their external partners' actions (Frączkiewicz-Wronka, 2012, p. 275; Kożuch \& Sienkiewicz-Małyjurek, 2013; Klijn \& Teisman, 2008). One of the reasons of the above situation is the fact that public organisations want to - or sometimes even have to - gain resources remaining at their partners' disposal (Frączkiewicz-Wronka, 2012, p. 277). As a consequence, the public sector is increasingly becoming organised and controlled (Peters, 1998) by interorganisational relations (Kastberg, 2016). However, the literature within the scope of interorganisational relations provides empirical evidence which proves that the efficiency of organisations can be increased via cooperation (Conteh, 2013). Nonetheless, cooperation of the public sector organisations with external entities is still controversial among some researchers. It is mostly because of the fact that cooperation may lead to disorientation in the public system since it is bound with the tendency to compromise (Singh 
\& Prakash, 2010). The problem is intensified by the fact that in reality there are very few guidelines for political leaders and managers of the public sector organisations which would provide them with advice in the process of managing interorganisational relations (Dickinson \& Glasby, 2010). More particularly as ensuring an effective implementation of mutual experiences and any individual solutions obligate the public sector managers to be equipped with skills such as sharing of ideas, resources, and power with other organisations, often non-public ones.

Thus, the subject of the ongoing discussion includes the rules of cooperation and mechanisms of implementing solutions (which are continuously changing in time) on particular levels of the public authority, as well as between the public and non-public sectors. It is worth noticing that neither the subject literature nor the Polish legislation in the scope of public finances contain one unequivocal definition of the public sector. Hence, this study assumes that the public sector is connected with the provision of important, cross-social goods and services which, due to their nature and unprofitability, cannot be provided by the private sector (Ziębicki, 2014, p. 107).

This study is a part of the above-mentioned debate with regard to particular public sector organisations such as public higher education institutions. The aim of this study is to identify the antecedence of building relations between public higher education institutions and external partners, as well as the areas in which those relations are used by cooperating entities in order to achieve their goals. The structure of this study has been conformed with this aim. The first part of the study presents the characteristics of relations between the public sector organisations and external entities. Considerations, conducted within this scope, concerning management of interorganisational relations in the public sector have been supported by the knowledge concerning interorganisational relations in principle regarding to private sector organisations. Such an approach (according to researchers) is justified (Hood, 1991).

In the second part there is focus on identifying the essence of functioning of public higher education institutions and the specific character of their relations with external stakeholders. The third part, on the basis of the results of literature analysis, indicates the antecedences of cooperation of public higher education institutions with external entities. 
The contents of the article is the result of conducting research of literature within the scope of public management, interorganisational relations, and functioning of public higher education institutions. The analysis has been executed in compliance with a specific methodological rigour (proper for this research method): starting from defining the aim of a research task and then selecting publications, analysing their contents and elaborating the results.

At the same time, in the future it is worth to pay attention to an increasingly used methodology of a systematic literature analysis, which is much more methodically reliable and it is not burdened with e.g. a fragmentation error or unclear criteria of selecting publications.

The given problem is important since the task of higher education institutions (organisations functioning within the public sector), and of their sub-system of interorganisational relations in particular, is to create favourable conditions for their proper adjustment to the environment, simultaneously ensuring high effectiveness of their functioning. Activities undertaken jointly with external organisations have an impact on increasing the quality of education via models transferred (adapted) to the needs of education of students and scientific personnel. Joint actions also have a positive impact on the results of research and development works, as well as on intensification of promoting their achievements. Enterprises often have significant financial resources which they can spend on conducting research. Higher education institutions, on the other hand, have a possibility to influence a significant number of recipients among whom the joint achievements of business and education institutions are promoted.

The above issue belongs to a research area regarding interorganisational relations in the public sector, which has still not been analysed to a large extent (Kastberg, 2016). This area constitutes an integral part of the New Public Governance (NPG) concept (Conteh, 2013; Kożuch, Kożuch \& Sienkiewicz-Małyjurek, 2016) which allows for reducing the insufficiency of knowledge about interorganisational relations in the public sector, among public higher education institutions in particular. 


\section{CHARACTERISTICS OF THE RELATION BETWEEN PUBLIC SECTOR ORGANISATIONS AND EXTERNAL ENTITIES}

Despite the fact that cooperating organisations in the public sector sometimes belong to the same parent organisation, it is however legitimate, according to researchers, to use the term of interorganisational relations (Cäker \& Siverbo, 2011). Cooperation among organisations in this sector is defined as mutually beneficial relations between two or among more than two organisations which aim is to achieve common goals (Parkinson, 2006). The phenomenon of cooperation means that organisations establishing it can be perceived as institutions building a characteristic form of an activity, or rather a form of cooperation of public entities with other organisations. They can also be perceived as new institutions created by the aforementioned entities in the process of achieving a common goal (Kożuch, 2011; Fraczkiewicz-Wronka \& Wronka-Pośpiech, 2016, p. 310).

Establishing a relation, on the other hand, means that its parties commit themselves to (Parkinson, 2006):

- mutual contacts and joint achievement of goals,

- joint development of both institutions,

- sharing of responsibility,

- joint authority,

- responsibility for success,

- sharing of resources and benefits.

The need to establish a cooperation relation with external entities occurs when a public organisation does not have characteristic resources, crucial for achieving goals connected with the provision of public and social goods, or when such an organisation is not capable of producing such resources in its own scope. Interorganisational relations fill in the cooperation space of autonomous organisations, created in view of their common or individual goals. Economic and social relations coexist inside of this space and management is executed on the basis of agreements and interpersonal decision processes (Czakon, 2005, p. 10-13). For the needs of this study, the following definition of interorganisational relations has been assumed: interactions occurring between public organisations and external entities, in which an informational, material, or energetic exchange takes place, while 
the parties to this exchange express their involvement and such an attitude is mutual (Czakon, 2007).

Involvement is what differentiates regular market transactions between contractors from cooperation between them. Involvement is perceived as an intention to undertake actions in the future, particularly to bear inputs to the benefit of a highly estimated relation with an external partner. A capital, informational and social involvement is a mechanism preventing, to a certain extent, from opportunism (Jap, Anderson, 2003). According to the research of S. Ganesan (1994), involvement may become reinforced when partners' trust levels increase. The latter can be influenced not only by fulfilling a partner's expectations but also by opinions disseminated by third parties.

Reality proves that often interorganisational relations in the public sector are not based on positive perceptions and a good will. A significant number of those relations is based on dependence on legal regulations and resources provided by external partners (suppliers) when there is a limited access to alternative solutions and costs of changing a partner are high. A state in which one of the parties to an exchange is clearly dominating the other one is called a dependence. On the other hand, a state in which the force of impact is divided relatively evenly is defined as interdependence.

Moreover, the features of interorganisational relations connecting the public sector organisations with external partners (fulfilling the roles of suppliers and recipients), apart from the above-mentioned elements, i.e. involvement and dependence, may include satisfaction and trust.

An exchange between the public sector organisations and external partners is, as a rule, based on the execution of proceedings regulated by law and on signing of an official agreement. In this context, legal bindings refer to the extent to which an agreement regulates the role and scope of parties' liability, in reference to both planned and unplanned events within cooperation. The occurrence of strong legal bindings does not exclude a high level of trust. On the contrary, in the case of cooperation those two factors coexist.

Cooperation is always based on some initial conditions. Partners, via their involvement in achieving those conditions, become familiar with their actions (Doz, 1996). Actions undergo changes, while ensuring a mutually coordinated activity requires a regularly renewed (periodic) cooperation assessment. Results obtained in such a manner constitute grounds for correcting cooperation conditions, if that proves to be 
necessary. In order to understand the way in which an assessment of benefits rising from relations with external partners should be executed, it is worth referring to the reasons why parties to a relation make an effort to establish such a relation at all. What is more, inputs which partners bring into their relation and benefits rising from it undergo changes in the process of cooperation which brings about a need to renegotiate the terms of their agreement.

Measuring and assessing the effects of cooperation between public organisations and external entities is one of the crucial and, at the same time, one of the most difficult tasks to be fulfilled by managers. When assessing the effects of cooperation, taking into account a time horizon seems to be especially essential. An activity assessment on the strategic level should be as important for managers as an assessment on the operational level. An assessment on the strategic level refers to a long time horizon. An assessment on the operational level puts an emphasis on a current activity.

Conducting a process of assessing an interorganisational relation requires not only defining the criteria and scope or introducing proper control tools, but also indicating model values. A model is necessary in order to assess the level of conformity of the actual functioning of an interorganisational relation with expectations formulated during its creation. The basic functions of indicators used when assessing interorganisational relations include measuring the economic phenomena (events, facts), on the basis of which a relation assessment is done. However, such an assessment is incomplete. Hence, the best solution for assessing relations between public organisations and external entities is to link financial indicators with non-financial ones, e.g. indicators assessing the social effectiveness of public organisations' functioning. Nevertheless, it needs to be emphasised that very often decisions leading to fast profits in the form of current financial results may destroy the achievement of social benefits in the future.

\section{AREAS OF ACTIVITY OF PUBLIC HIGHER EDUCATION INSTITUTIONS}

A higher education institution, under the Act on Higher Education, is defined as an education institution running higher education, whose creation is determined by the Act. It is autonomous in all areas of 
its activity on the grounds determined in the Act. A public higher education institution, which functions in the area of public finances, is formed by the state which is represented by a competent authority or a public administration body.

Table 1. The number of public higher education institutions in particular groups in the years 2005-2014

\begin{tabular}{|l|c|c|c|c|c|c|c|c|c|c|c|}
\hline \multirow{2}{*}{$\begin{array}{c}\text { Higher } \\
\text { education } \\
\text { institutions }\end{array}$} & Group & \multicolumn{7}{|c|}{ Years } \\
\cline { 2 - 12 } & 2005 & 2006 & 2007 & 2008 & 2009 & 2010 & 2011 & 2012 & 2013 & 2014 \\
\hline Universities & I & 17 & 17 & 17 & 17 & 18 & 18 & 18 & 18 & 18 & 18 \\
\hline $\begin{array}{l}\text { Technical } \\
\text { higher } \\
\text { education } \\
\text { institutions }\end{array}$ & II & 18 & 18 & 18 & 18 & 17 & 17 & 18 & 18 & 18 & 18 \\
\hline $\begin{array}{l}\text { Agricultural } \\
\text { universities }\end{array}$ & III & 8 & 7 & 7 & 7 & 6 & 6 & 6 & 6 & 6 & 6 \\
\hline $\begin{array}{l}\text { Economic } \\
\text { higher educa- } \\
\text { tion institutions }\end{array}$ & IV & 5 & 5 & 5 & 5 & 5 & 5 & 5 & 5 & 5 & 5 \\
\hline $\begin{array}{l}\text { Pedagogic } \\
\text { higher educa- } \\
\text { tion institutions }\end{array}$ & V & 6 & 6 & 6 & 6 & 6 & 6 & 5 & 5 & 5 & 5 \\
\hline $\begin{array}{l}\text { Medical } \\
\text { academies }\end{array}$ & VI & 9 & 9 & 9 & 9 & 9 & 9 & 9 & 9 & 9 & 9 \\
\hline $\begin{array}{l}\text { Physical educa- } \\
\text { tion academies }\end{array}$ & VII & 6 & 6 & 6 & 6 & 6 & 6 & 6 & 6 & 6 & 6 \\
\hline $\begin{array}{l}\text { Artistic higher } \\
\text { education } \\
\text { institutions }\end{array}$ & VIII & 18 & 18 & 18 & 18 & 18 & 19 & 19 & 19 & 19 & 19 \\
\hline $\begin{array}{l}\text { Vocational high- } \\
\text { er education } \\
\text { institutions }\end{array}$ & IX & 30 & 34 & 35 & 36 & 36 & 36 & 36 & 36 & 36 & 36 \\
\hline $\begin{array}{l}\text { Other higher } \\
\text { education } \\
\text { institutions }\end{array}$ & X & 4 & 10 & 10 & 10 & 10 & 10 & 10 & 10 & 10 & 10 \\
\hline $\begin{array}{l}\text { Public higher education } \\
\text { institutions in total }\end{array}$ & 124 & 130 & 131 & 131 & 131 & 132 & 132 & 132 & 132 & 132 \\
\hline
\end{tabular}

Source: own study on the basis of the data of Central Statistical Office of Poland for the years 2005-2014.

According to the Central Statistical Office of Poland, public higher education institutions are divided into ten following groups (Table 1): universities (group I), technical higher education institutions (group II), 
agricultural universities (group III), economic higher education institutions (group IV), pedagogic higher education institutions (group V), medical academies (group VI), physical education academies (group VII), artistic higher education institutions (group VIII), vocational higher education institutions (group IX), and other higher education institutions (group X).

According to legal regulations currently in force (mainly the Act on Higher Education), the didactic activity (DA) constitutes the fundamental area of a higher education institution's functioning. In the frame of this activity the following tasks are realised: education of students of the $1^{\text {st }}, 2^{\text {nd }}$, and $3^{\text {rd }}$ degree, education of participants of post-graduate studies, education of participants of courses and trainings, as well as education of an institution's scientific personnel. Next, there is the research activity (RA) which covers conducting research and development works and providing research services.

The above-mentioned regulations also indicate the third area of functioning of public higher education institutions: separated economic activity (SEA) - distinguished within higher education institutions. It is executed in the form of an activity supporting the realisation of the primary tasks of an education institution and it aims at improving its economic effectiveness.

The area of the remaining operational activity (ROA) does not include the realisation of objectives of public higher education institutions. Actions undertaken in the frame of ROA occur as a result of operational (fundamental) activities of higher education institutions.

Table 2. The areas of the operational activity of higher education institutions

\begin{tabular}{|c|c|c|}
\hline \multicolumn{2}{|c|}{ Operational activity of higher education institutions (OA) } \\
\hline $\begin{array}{c}\text { Didactic activity } \\
\text { (DA) }\end{array}$ & $\begin{array}{c}\text { Research activity } \\
\text { (RA) }\end{array}$ & $\begin{array}{c}\text { Separated economic activity } \\
\text { (SEA) }\end{array}$ \\
\hline \multicolumn{2}{|c|}{ Remaining operational activity (ROA) } \\
\hline \multicolumn{2}{|c|}{} \\
\hline
\end{tabular}

Source: own study on the basis of the Act on Higher Education and the Ordinance of the Minister of Science and Higher Education regarding the detailed rules of the financial management of public higher education institutions.

Table 2 presents segments of the operational activity of a higher education institution. Three fundamental activities have been distinguished within it: didactic, research, and economic. They are 
supplemented by the remaining operational activity in which events influencing all the elements of the operational activity of public higher educational institutions occur.

\section{EXTERNAL ENTITIES WHICH ESTABLISH RELATIONS WITH HIGHER EDUCATION INSTITUTIONS}

By establishing relations with external organisations, higher education institutions aim at an effective realisation of tasks imposed on them by the regulations of the Act on Higher Education. Those relations are particularly expected to contribute to increasing the economic and social effectiveness of higher education institutions' functioning. Nevertheless, it is mostly expected that higher education institutions, via relations established with external organisations, will contribute to development of knowledge and dissemination of research results.

Figure 1 presents the groups of organisations cooperating with higher education institutions. Due to the areas of cooperation, they build not only relations leading to an effective realisation of tasks, but also, and above all, relations resulting in new solutions, improving functioning of the economy. The first group (Group I) is comprised of higher education institutions, the remaining scientific institutions including the institutes of the Polish Academy of Sciences, the Polish Academy of Learning, and research institutes. All these units have an impact on the state scientific policy, they are decision-making bodies and advisory bodies. Other organisations, which also belong to the above group, include the following science supporting entities: the National Science Centre, the National Centre for Research and Development, archives, museums, national libraries, associations, scientific foundations, as well as central administration bodies, and NGOs.

Organisations which are special due to the complexity of legal regulations and the way they influence the behaviour of public higher education institutions include, inter alia: the Conference of Rectors of Polish Universities (KRUP) and the Conference of Rectors of Academic Schools in Poland (KRASP). These organisations associate authorities of higher education institutions in order to develop common and uniform solutions and positions, represented before competent ministries with the aim of an effective execution of tasks. The Central Commission for Degrees and Titles regulates and coordinates procedures related 
to conferring scientific degrees and titles. The aim of the State Accreditation Committee is to guarantee the quality of education in the higher education area and its continuous improvement. Relations between higher education institutions and organisations functioning in Group I are regulated by law, and cooperation with them is mostly obligatory due to the standards required from actions undertaken by higher education institutions.

The public administration (Group II) establishes relations with higher education institutions primarily via obligatory solutions. These mainly include legal regulations directly referring to authorities of higher education institutions (the Act on Higher Education, inter alia) or to authorities of entities which belong to the public finance sector (the Public Finance Act, inter alia). Since the subsidy granted in accordance with the state budget plan is the main source of financing activities of public higher education institutions, any financial settlements related to finances obtained from the above source, as well as their proper spending are coordinated by the public administration units. Those units also include organisations of public reporting, such as: the Central Statistical Office of Poland and competent ministries which coordinate and support the activities of higher education institutions.

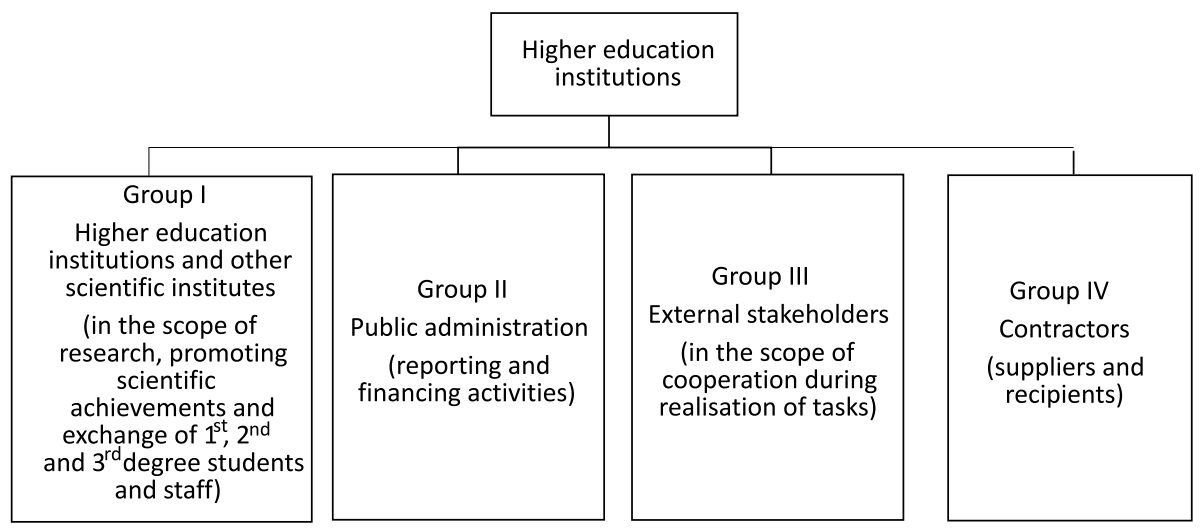

Figure 1. Groups of organisational units which establish relations with higher education institutions

Source: own study.

Another group (Group III) which higher education institutions establish relations with comprises of entities (external stakeholders) with whom cooperation is primarily expected to ensure a high quality 
of education and conducting research resulting in new technological and organisational solutions and to enable introducing new products (goods and services) onto the market. For instance, cooperation of higher education institutions and enterprises also consists in education with the participation of potential employers, as well as in joint elaboration of study specialisations and education by the order of those enterprises. The motivation of enterprises' management boards to the continuous search for results of research and development works, new concepts, ideas, and inventions and putting them into practice leads to innovativeness, and through innovativeness - to competitiveness of the entire economy (Ministerstwo Gospodarki, 2011, p. 3). Innovativeness of enterprises creates novel solutions in the whole country's resources which contributes to its competitiveness. As a result, there is an increase of the country's Gross Domestic Product (GDP).

Relations between enterprises and higher education institutions are also favourable to (Lee, 2011):

- absorbing knowledge with crucial meaning for future innovations. The effectiveness of the public sector is dependent on innovations and creativity (Głód, 2012, p. 111),

- solving technological problems concerning production goods and processes,

- acquiring access to necessary human capital.

According to the resolutions of the Bologna Process, higher education institutions shall introduce a reform of processes occurring inside of them and shall inform the local authorities and future employers about the reform's progress. Information about the progress of works connected with reorganising the higher education, transferred to the environment, will allow for a greater involvement of enterprises' management boards in the process.

The group of entities which public higher education institutions establish relations with also includes (Group IV):

- suppliers of materials, goods, and services,

- recipients who benefit from the effects of a higher education institution's activities.

They comprise, above all, the $1^{\text {st }}, 2^{\text {nd }}$ and $3^{\text {rd }}$ degree students, participants of post-graduate studies, and participants of courses and trainings.

The fact that the quality of relations between public higher education institutions and the above-mentioned groups of external entities have 
a direct or indirect impact on the amount of subsidy obtained from the state budget is the fundamental prerequisite persuading those institutions to establish and maintain such relations. The effects of their activities in particular areas have been taken into account in the algorithm which serves for establishing the amount of subsidy for particular higher education institutions.

\section{RELATIONS BETWEEN PUBLIC HIGHER EDUCATION INSTITUTIONS AND EXTERNAL ENTITIES - IDENTIFICATION OF THE ANTECEDENCE OF THEIR CREATION}

The indicated characteristics of interorganisational relations in the public sector also refer to relations between public higher education institutions and other organisations. Establishing relations between education institutions and external entities and taking advantage of them may provide both parties with numerous benefits, which has been proven by a significant number of empirical research results (e.g. Turpin et al., 1996; Etzkowitz \& Klofsten, 2005; Lee, 2011). For instance, effective research cooperation provides universities with funds for research, they enable to put the research results into practice and have an insight into new research areas. In turn, external entities gain an opportunity to absorb new knowledge of crucial meaning for future innovations, to solve technological problems concerning production goods and services and to gain access to the human capital (Lee, 2011). On the other hand, indicating dependences being the consequence of interorganisational relations constitutes the most fundamental challenge for measuring the effectiveness of such relations in the public sector (Lacey, Cuganesan, Goode \& Jacobs, 2012).

Thus, cooperation can be referred to the involvement of various entities in joint work in a long period of time, having in mind the benefits which could not be achieved by any single entity functioning outside of a cooperation scheme. Cooperation of partners is based on solid and durable relations in which both parties mutually develop products, share risks, costs, and benefits, as well as ensure mutual value adding (Klijn \& Teisman, 2008). 
D.A. Whetten (1981) indicated four main types of interorganisational relations in the public sector, as follows:

1. relations between two parties (dyads); relations of this type indicate cooperation between two autonomous organisations, accompanied by a low level of resource involvement (Oliver, 1990; Singh \& Prakash, 2010),

2. collections (structures) of organisations; they constitute the sum of interorganisational relations established among an organisation with the central position and the other participants of a given structure,

3. collections (structures) of actions; they form a constellation of relations of organisations which jointly realise a determined objective,

4. cooperation networks; they are a sub-system comprising of various combinations of interorganisational relations (Whetten, 1981). A cooperation network constitutes a set of highly formalised and integrated common actions. A network is defined as formal and informal structures consisting of representatives of government agencies and NGOs, demonstrating interdependence in the scope of information exchange and/or common formulation and implementation of policy which is usually designed to be executed by particular organisations (Cooper, 2015).

Domination of cooperation, which is observable in the realisation of the policy of the public sector entities, does not assume resigning from other forms of its implementation, i.e. a hierarchy and the market. Those three forms of policy implementation in the public sector coexist altogether (Osborne, 2006). Similarly to the market and hierarchy, relations are mechanisms of coordination. The main difference among them all is the fact that a hierarchy rather relies on rules and order, whereas the market and relations are based on trust and cooperation (Cooper, 2015).

There is another criterion which can be used when classifying interorganisational relations in the public sector - the law. Using this criterion allows for the separation of obligatory relations (by virtue of law) and facultative ones.

Relations between public higher education institutions and external entities are primarily related to the expected realisation of common aims concerning mainly the education, conducting research and promoting 
its results. Owing to the fact that public higher education institutions function on the grounds of the public sector's legal regulations, relations established by them are mainly based on the regulations concerning organisations of this sector.

Figure 2 presents the types of relations between public higher education institutions and external entities, distinguished according to the assumed criterion of their creation in reference to legal regulations. They are divided into obligatory relations (regulated by law) and facultative relations (created intentionally in view of the expected benefits).

Realisation of the operational activity (OA) of a higher education institution which, in a synthetic structure, has been classified in three areas: DA, RA, and SEA (see Table 2) is significantly supported by cooperation with external entities.

It should also be noticed that, apart from the above mentioned formal relations, public higher education institutions establish informal (facultative) relations with external entities as well. The aim of such informal relations is to formulate new approaches and consult new solutions.

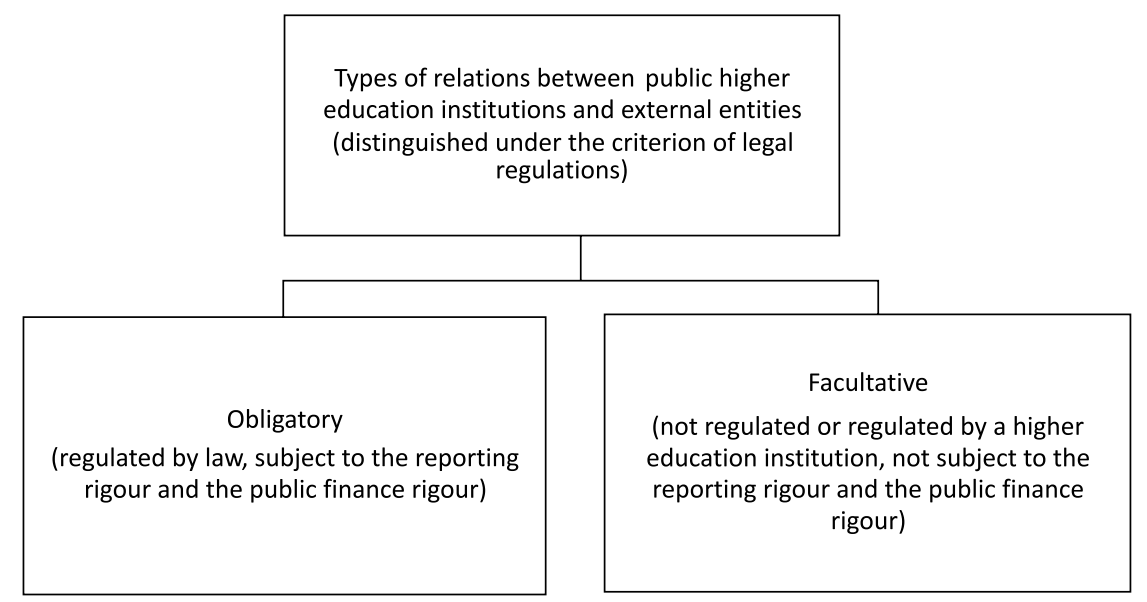

Figure 2. Relations between public higher education institutions and external entities

Source: own study.

Table 3 indicates selected legal regulations connected with relations arising in given segments of the operational activity of a higher education institution. These regulations also coordinate cooperation 
with external entities in the scope of realised tasks of DA, RA, and SEA (see Table 2).

The Act on Higher Education is the primary legal act in all areas of the operational activity of public higher education institutions which realise their didactic tasks, research tasks, and tasks concerning economic activity on the basis of the Act. Due to the diversity of tasks realised by higher education institutions (in compliance with Art. 13 of the Act on Higher Education), units managing such institutions have to obey numerous legal regulations and their interpretations. Abiding by those regulations is necessary and in each case it determines decisions made by units managing an education institution.

Table 3. Legal regulations of fundamental areas of functioning of public higher education institutions

\begin{tabular}{|c|c|c|c|}
\hline $\begin{array}{l}\text { Types of } \\
\text { regulation }\end{array}$ & $\begin{array}{l}\text { Didactic activity } \\
\text { (DA) }\end{array}$ & $\begin{array}{l}\text { Research activity } \\
\text { (RA) }\end{array}$ & $\begin{array}{l}\text { Separated economic } \\
\text { activity (SEA) }\end{array}$ \\
\hline 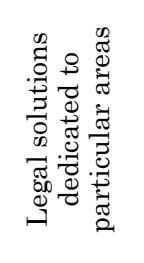 & $\begin{array}{l}\text { Joint Declaration of } \\
\text { the European Min- } \\
\text { isters of Education } \\
\text { - The Act on Aca- } \\
\text { demic Degrees and } \\
\text { Title and Degrees } \\
\text { and Title in the } \\
\text { Arts }\end{array}$ & $\begin{array}{l}\text { The Act on the Prin- } \\
\text { ciples of Financing } \\
\text { Science } \\
\text { - The Act on Academ- } \\
\text { ic Degrees and Title } \\
\text { and Degrees and } \\
\text { Title in the Arts }\end{array}$ & $\begin{array}{l}\text { - The Economic Free- } \\
\text { dom Act } \\
\text { - The Accounting Act } \\
\text { - The Corporate In- } \\
\text { come Tax Act } \\
\text { - The Act on VAT }\end{array}$ \\
\hline 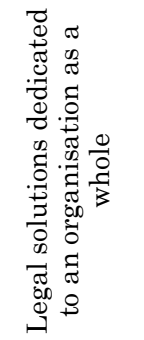 & \multicolumn{3}{|c|}{$\begin{array}{l}\text { - The Act on Higher Education } \\
\text { - The Public Finance Act } \\
\text { - The Act on Breach of Public Finance Discipline } \\
\text { - Ordinance regarding the detailed rules of the financial management of } \\
\text { public higher education institutions } \\
\text { - Ordinance regarding the allocation of state budget funds for public and } \\
\text { private higher education institutions } \\
\text { - The Public Procurement Act } \\
\text { Income Tax Act, the Act on VAT) }\end{array}$} \\
\hline
\end{tabular}

Source: own study on the basis of selected legal regulations.

Tasks performed in the area of DA (see Table 3), above all consisting in education, are regulated on the international level. The aim of such a solution is to trigger the creation of relations among higher education institutions and enterprises in Europe and in the entire world.

The objectives of RA include conducting research and development works and providing research services. Due to relations arising between education institutions and external entities, actions within this area have an impact on dissemination of research results, achieved by 
education institutions. Legal regulations coordinating those actions are expected to support their effectiveness.

In turn, the economic activity (SEA) of public higher education institutions is subject to legal regulations under general conditions, concerning functioning of the public sector area which realises economic activities, particularly taking the tax regulations into account.

In light of the above considerations, it is possible to state that the law is the antecedence of creating relations between public higher education institutions and external entities.

\section{SUMMARY AND CONCLUSIONS}

In this study the antecedence and areas of building and maintaining relations between public higher education institutions and external partners have been identified. It has been noticed that the group of entities cooperating with higher education institutions in the areas of DA and RA primarily includes other higher education institutions, institutes of the Polish Academy of Sciences, the Polish Academy of Learning, and research institutes. Organisations supporting science also comprise: the National Science Centre, the National Centre for Research and Development, archives, museums, national libraries, associations, scientific foundations, as well as central administration bodies, and NGOs. All these units have an impact on the state scientific policy, they are decision-making bodies and advisory bodies. By building relations with higher education institutions, entities not only aim at an effective realisation of tasks, but also, and above all, they strive for new solutions improving functioning of the society and the entire economy. Entities cooperating within the realisation of tasks in the SEA area primarily consist of suppliers of materials, goods and services, as well as of recipients who benefit from the effects of a higher education institution's activities in this area.

Relations of public higher education institutions and external entities are mainly orientated on education, conducting research, and promoting results of this research. Moreover, it has been indicated that establishing and taking advantage of such relations is executed on the basis of legal regulations coordinating activities of the public sector organisations. Legal regulations improve the realisation of tasks in the scope of DA, RA, and SEA, they facilitate functioning of higher education institutions 
and support decisions concerning the management of such complex organisations. Higher education institutions also establish informal relations resulting in the formulation of numerous new approaches and the introduction of solutions alternating the previous activities.

Long-term relations with organisations, especially with other higher education institutions and scientific institutions, have an impact on shaping opinions and attitudes. What is more, they determine the direction of their actions. Due to the fact that higher education institutions are characterised by a certain mission, a relatively similar action strategy and the same tasks, and despite their differences resulting from their autonomy, they function in a similar way - by promoting identical values. Higher education institutions influence the achievement of the national social and economic objectives and they build the country's intellectual and social capital. Two fundamental functions, linked with each other, of higher education institutions (i.e. education and conducting research) have a crucial meaning for the ability of business entities and societies to adjust to changes, they also influence shaping the future.

In light of the obtained research results, identifying the types of relations between public higher education institutions and particular external entities, and simultaneously determining the level of dependence of their actions on their partners' undertakings, seems to be intriguing. It is also worth identifying whether the above relations create favourable conditions for a transfer of knowledge between organisations and what kind of knowledge this is. Dependence on entities' functioning, indicated in this study and resulting from interorganisational relations, constitutes a challenge for measuring the effectiveness of such relations in the public sector.

\section{REFERENCES}

Cäker, M. \& Siverbo, S. (2011). Management control in public sector joint ventures, Management Accounting Research, 22(4), 330-348.

Conteh, Ch. (2013). Strategic inter-organizational cooperation in complex environments, Public Management Review, 15(4), 501-521.

Cooper, T. (2015). Empirical research on inter-organizational relations within a national disaster management network in the Caribbean, Public Organization Review, 15, 1-16. 
Czakon, W. (2005). Istota relacji sieciowych przedsiębiorstwa, Przeglad Organizacji, $9,10-13$.

Czakon, W. (2007). Dynamika więzi międzyorganizacyjnych przedsiębiorstwa. Katowice: Wydawnictwo Akademii Ekonomicznej w Katowicach.

Jap S.D. \& Anderson E. (2003). Safeguarding interorganizational performance and continuity under ex post opportunism, Management Science, 49(12).

Ganesan, S. (1994). Determinants of long term orientation in buyer-seller relationships, Journal of Marketing, 58(2).

Doz, Y. (1996). The evolution of cooperation in strategic alliances: initial conditions or learning process, Strategic Management Journal, 17.

Dickinson, H. \& Glasby J. (2010). Why partnership working doesn't work': Pitfalls, problems and possibilities in English health and social care, Public Management Review, 12(6), 811-828.

Etzkowitz, H. \& Klofsten, M. (2005). The innovating region: toward a theory of knowledge-based regional development, R\&D Management, 35(3), 243-255.

Frączkiewicz-Wronka, A. (2012). Analiza interesariuszy jako metoda wspierająca formułowanie strategicznych zamierzeń w organizacji. In: R. Krupski (ed.), Metody badań problemów zarządzania strategicznego, Prace Naukowe Wałbrzyskiej Wyższej Szkoły Zarzadzania i Przedsiębiorczości, 17, 269-292.

Frączkiewicz-Wronka, A. \& Wronka-Pośpiech, M. (2016). Analiza wybranych form współpracy między partnerami w partnerstwach publiczno-społecznych. In: A. Zakrzewska-Bielawska (ed.), Stan i perspektywy rozwoju nauk o zarzadzaniu. Torun: Dom Organizatora TNOiK.

Głód, G. (2012). Przedsiębiorczość publiczna w kontekście zarządzania zmianą w jednostkach ochrony zdrowia. In: A. Stabryła, K. Woźniak (eds.), Determinanty potencjału organizacji. Mfiles, Kraków.

Główny Urząd Statystyczny (2006-2015). Szkoty wyższe i ich finanse w 2005-2014. Warszawa: Wydawnictwo GUS.

Hood, C. (1991). A New Public Management for all seasons? Public Administration, 69(1), 3-19.

Joint Declaration of the European Ministers of Education, collected in Bologna on 19 June 1999.

Kastberg, G. (2016). Trust and control in network relations: A study of a public sector setting, Financial Accountability \& Management, 32(1), 33-56.

Klijn, E.-H. \& Teisman, G.R. (2008). Complexity theory and public management, Public Management Review, 10(3), 287-297.

Kożuch, B. (2011). Skuteczne współdziałanie organizacji publicznych i pozarzadowych. Kraków: Monografie i Studia Instytutu Spraw Publicznych. 
Kożuch, B., Kożuch, A. \& Sienkiewicz-Małyjurek, K. (2016). Contemporary faces of public management, Przeglad Organizacji, 3, 56-63.

Kożuch, B. \& Sienkiewicz-Małyjurek, K. (2013). Mierzenie skuteczności współpracy międzyorganizacyjnej w zarządzaniu bezpieczeństwem publicznym, Studia Uniwersytetu Ekonomicznego w Katowicach, 168, 82-95.

Lacey, D., Cuganesan, S., Goode, S. \& Jacobs, K. (2012). Celebrating adversity: Inter-organizational dependence and public sector performance reporting in the Australian Federal Police, Public Administration, 90(2), 393-411.

Lee, K.-J. (2011). From interpersonal networks to inter-organizational alliances for university-industry collaborations in Japan: The case of the Tokyo Institute of Technology, R\&D Management, 41(2), 190-201.

Ministerstwo Gospodarki (2011). Strategia innowacyjności i efektywności gospodarki, Warszawa, 3.

Oliver, C. (1990). Determinants of inter-organizational relationships: Integration and future directions, Academy of Management Review, 15(2), 241-265.

Osborne, S.P. (2006). The New Public Governance? Public Management Review, 8(3), 377-387.

Parkinson, C. (2006). Building successful collaborations: A guide to collaboration among nonprofit agencies and business, Cambridge and North Dumfries Community Foundation, September. Retrieved from: www.cfc-fcc.ca/link_docs/ collaborationReport.pdf (access: 17.04.2016).

Peters, B.G. (1998). Managing horizontal government: The politics of co-ordination, Public Administration, 76(3), 295-316.

Rozporządzenie Ministra Nauki i Szkolnictwa Wyższego w sprawie sposobu podziału dotacji z budżetu państwa dla uczelni Publicznych i niepublicznych (Ordinance of the Minister of Science and Higher Education regarding the allocation of state budget funds for public and private higher education institutions), Dz.U. (Journal of Laws) of 2012, item 202 of 8 February 2012.

Rozporządzenie Ministra Nauki i Szkolnictwa Wyższego w sprawie zakresu I trybu realizacji programu naprawczego prowadzącego do uzyskania równowagi finansowej uczelni publicznej (Ordinance of the Minister of Science and Higher Education regarding the scope and procedure of the realization of a repair programme resulting in achievement of financial balance of a higher education institution), Dz.U. (Journal of Laws) No. 243, item 1446 of 5 October 2011.

Rozporządzenie Rady Ministrów w sprawie szczegółowych zasad gospodarki finansowej uczelni publicznych (Ordinance of the Council of Ministers regarding the detailed rules of the financial management of public higher education institutions), Dz.U. (Journal of Laws) item 1533 of 18 December 2012. 
Singh, A. \& Prakash, G. (2010). Public-private partnerships in health services delivery: A network organizations perspective, Public Management Review, 12(6), 829-856.

Turpin, T., Garrett-Jone, S. \& Rankin, N. (1996). Bricoleurs and boundary riders: managing basic research and innovation knowledge networks, $R \& D$ Management, 26(3), 267-282.

Ustawa o finansach Publicznych (The Public Finance Act), Dz.U. (Journal of Laws) No. 157, item 1241 of 27 August 2009.

Ustawa o odpowiedzialności za naruszenie dyscypliny finansów publicznych (The Act on Breach of Public Finance Discipline), Dz.U. (Journal of Laws) No. 14, item 114 of 17 December 2004.

Ustawa o podatku dochodowym od osób fizycznych (The Personal Income Tax Act), Dz.U. (Journal of Laws) No. 80, item 350 of 26 July 1991.

Ustawa o podatku dochodowym od osób prawnych (The Corporate Income Tax Act), Dz.U. (Journal of Laws) No. 21, item 86 of 15 February1992.

Ustawa o podatku od towarów i usług (The Act on VAT), Dz.U. (Journal of Laws) No. 54, item 535 of 11 March 2004.

Ustawa o rachunkowości (The Accounting Act), Dz.U. (Journal of Laws) No. 121, item 591 of 29 September 1994 as amended.

Ustawa o stopniach naukowych i tytule naukowym oraz o stopniach i tytule w zakresie sztuki (The Act on Academic Degrees and Title and Degrees and Title in the Arts), Dz.U. (Journal of Laws) No. 65, item 595 of 14 March 2003 as amended - consolidated text.

Ustawa o swobodzie działalności gospodarczej (The Economic Freedom Act), Dz.U. (Journal of Laws) No. 173, item 1807 of 2 July 2004.

Ustawa prawo o szkolnictwie wyższym (The Act on Higher Education), Dz.U. (Journal of Laws) No. 164, item 1365 of 27 July 2005 as amended.

Ustawa prawo zamówień publicznych (The Public Procurement Act), Dz.U. (Journal of Laws) No. 19, item 177 of 29 January 2004.

Whetten, D.A. (1981). Interorganizational relations: A review of the field, Journal of Higher Education, 52(1), 1-28.

Ziębicki, B. (2014). Efektywność organizacyjna podmiotów sektora publicznego. Kraków: Wydawnictwo Uniwersytetu Ekonomicznego w Krakowie. 


\title{
ANTECEDENCJE WSPÓKDZIAKANIA PUBLICZNYCH SZKÓk WYŻSZYCH Z PODMIOTAMI ZEWNĘTRZYMI. UJĘCIE LITERATUROWE
}

\begin{abstract}
Abstrakt
Tło badań. Niniejsze opracowanie wpisuje się w debatę w odniesieniu do wybranych organizacji sektora publicznego, jakimi sa publiczne uczelnie, ponieważ ma na celu rozpoznanie antecedencji współdziałania publicznych szkół wyższych z podmiotami zewnętrznymi. Podjęty problem jest ważny, gdyż publiczne szkoły wyższe, a w szczególności ich podsystem relacji międzyorganizacyjnych, mają za zadanie sprzyjać odpowiedniemu ich dopasowaniu do otoczenia, przy jednoczesnym zapewnieniu ich efektywności.
\end{abstract}

Cel badań. Celem opracowania jest rozpoznanie antecedencji tworzenia relacji publicznych szkół wyższych z partnerami zewnętrznymi oraz obszarów, w których relacje te są przez współdziałające podmioty wykorzystywane do osiagania celów. Celowi temu podporządkowano strukturę opracowania. I tak w części pierwszej przedstawiono charakterystykę relacji organizacji sektora publicznego z podmiotami zewnętrznymi. W części drugiej skoncentrowano się na identyfikacji istoty działalności publicznych szkół wyższych i specyfiki ich relacji z interesariuszami zewnętrznymi. Z kolei w części trzeciej, na bazie wyników studiów literatury, wskazano antecedencje współdziałania publicznych szkół wyższych publicznych z podmiotami zewnętrznymi.

Metodyka. Treści zawarte w artykule są rezultatem przeprowadzonych studiów literatury z zakresu zarządzania publicznego, relacji międzyorganizacyjnych oraz działalności publicznych uczelni wyższych. Przy czym należy zauważyć, że przegląd ten został dokonany $\mathrm{z}$ zachowaniem odpowiedniego dla tej metody badań określonego rygoru metodycznego: od określenia celu badania poprzez wybór publikacji, analizę treści i opracowanie rezultatów.

Kluczowe wnioski. Publiczne szkoły wyższe, tworząc relacje z organizacjami zewnętrznymi, dążą do skutecznej realizacji zadań nałożonych na nie przez Ustawę prawo o szkolnictwie wyższym (UPoSW). W szczególności oczekiwanym jest, by relacje te przyczyniły się do zwiększenia efektywności ekonomicznej i społecznej tych szkół. Jednak przede wszystkim chodzi o to, by uczelnie publiczne, poprzez wykorzystywanie relacji z innymi organizacjami, przyczyniały się do rozwoju wiedzy. W świetle uzyskanych wyników badań, intrygujaccym wydaje się rozpoznanie typów relacji, jakie łączą publiczne szkoły wyższe z poszczególnymi podmiotami zewnętrznymi, a tym samym określenie stopnia uzależnienia podejmowanych przez nie działań od zachowań partnerów.

Słowa kluczowe: publiczne szkoły wyższe, relacje międzyorganizacyjne, współdziałanie. 